\title{
STRATEGI GURU DALAM MEMBENTUK KARAKTER SISWA MI TERPADU MUTIARA KOTA PADANGSIDIMPUAN
}

\author{
Darliana Sormin dan Fatimah Rahma Rangkuti \\ Universitas Muhammadiyah Tapanuli Selatan \\ darliana.sormin@um-tapsel.ac.id
}

\begin{abstract}
This research is about teacher's strategues in forming the students' characters at Madrasah Ibtidaiyah Terpadu Mutiara Padangsidimpuan. There is a special character of this school in implementing characterized curriculum based fitrah. It ws done qualitatively by describing the phenomeneon in the field. The teachers' strategies are gpd, and the students can apply the characters in their daily life, in school and at home as an Islamic teaching. The teachers' strategies in forming the students' characters through applying the active partisipatory learning, creating the condusive learning environment, giving eduacted character explisitly, sistematically, and continuosly by involving moral knowing, moral feeling, and moral action aspects.
\end{abstract}

Keywords: Strategies; Teachers; and Forming Character.

\begin{abstract}
Abstrak
Penelitian ini merupakan kajian terhadap Strategi Guru Dalam Membentuk Karakter Siswa MI Terpadu Mutiara Kota Padangsidimpuan. Alasan memilih judul disebabkan karena belum ada yang mengkaji masalah strategi pembelajaran dalam membentuk karakter siswa di MI Trepadu Mutiara. Peneliti menemukan ada ciri khas dari sekolah ini terkait kurikulum berkarakter yang berbasis fitrah. Strategi Guru Dalam Membentuk Karakter Siswa MI Terpadu Mutiara Kota Padangsidimpuan sudah baik dan bagus sehingga siswa dapat melaksanakan dalam kehidupan sehari - hari baik di rumah maupun di sekolah sesuai dengan ajaran Islam. Adapun Strategi Guru Dalam Membentuk Karakter Siswa MI Terpadu Mutiara Kota Padangsidimpuan melalui, Guru menerapkan metode pembelajaran yang melibatkan partisipatif aktif siswa. Guru menciptakan lingkungan belajar yang kondusif. Guru memberikan pendidikan karakter secara eksplisit, sistematis, dan berkesinambungan dengan melibatkan aspek moral knowing, moral feeling, moral action.
\end{abstract}

Kata Kunci: Strategi; Guru; dan Membentuk karakter,

\section{PENDAHULUAN}

Selama ini banyak pemikiran dan kebijakan dalam rangka peningkatan kualitas pendidikan, yang diharapkan mampu memberikan nuansa baru bagi pengembangan sistem pendidikan di Indonesia. Namun, dalam beberapa hal agaknya pemikiran konseptual tersebut terkesan idealis dan kurang realistis sehingga para pelaksana dilapangan sering mengalami hambatan untuk merealisasikannya. Rendahnya kualitas guru untuk menjalankan profesinya 
dalam tiga dasawarsa terahir telah mendapatkan perhatian dari masyarakat. Bahwa faktor kemampuan atau kompetensi guru sangat mempengaruhi rendahnya mutu pendidikan yang tengah dialami oleh bangsa Indonesia. Oleh karena itu peningkatan kemampuan guru khususnya dalam pelaksanaan proses pembelajaran menjadi fokus untuk meningkatkan kualitas murid.

Guru yang berperan dalam proses pembelajaran dituntut untuk terus menerus mengikuti perkembangan baru dalam dunia pendidikan. Sebagai guru harus mampu menggunakan strategi pembelajaran yang digunakan dalam mengajar, guru harus mengelola kelas dengan berbagai strategi pembelajaran sesuai dengan materi yang diajarkan.

Dalam menggunakan strategi pembelajaran, guru hendaknya mampu mengelola semua komponen yang ada dalam kegiatan proses pembelajaran hendaknya disusun secara sistematis untuk membantu memudahkan murid belajar. Komponen-komponen dalam kegiatan proses pembelajaran antara lain guru, murid, materi, strategi, metode, alat atau media, dan waktu. Tugas untuk menyusun rencana dan melaksanakan strategi pembelajaran memerlukan suatu kemampuan dari guru. Untuk itu guru harus memiliki pengetahuan tentang strategi pembelajaran akan memberikan landasan ilmiah tentang bagaimana menyusun dan menyelenggarakan kegiatan belajar mengajar yang dapat memudahkan siswa belajar sehingga tercapainya tujuan pembelajaran sesuai dengan harapan atau tujuan pendidikan nasional.

Guru dituntut untuk menguasai pengetahuan yang luas mengenai pendidikan dan sejumlah besar keterampilan professional dalam pembelajaran. Hal ini menunjukkan bahwa mengajar di sekolah dasar khususnya dalam pendekatan pembelajaran hendaknya mengutamakan prinsip murid agar ia senang belajar. ${ }^{1}$

Strategi guru dalam membentuk karakter murid sangatlah penting, dimana guru tersebut harus berusaha menjadi guru ideal, di samping menjadi contoh moralitas yang baik, diharapkan guru memiliki wawasan keilmuan dan pengetahuan yang luas sehingga materi yang disampaikan dapat ditinjau dari berbagai disiplin keilmuan yang lain. Memahami psikologi murid sangat diperlukan pula. Guru dalam mentransfer nilai tidak hanya diberikan dalam bentuk ceramah, tetapi bagaimana guru berkreasi dalam memberikan strategi 
pembelajaran kepada murid, sehingga suasana belajar tidak monoton dan murid terasa menyenangkan dan tidak bosan dengan suasana belajar. Guru diharapkan mengikuti perkembangan metode dan strategi pembelajaran mutakhir untuk menggunakan media teknologi informasi dalam pembelajarannya demi untuk memberikan yang terbaik kepada murid kedepannya. ${ }^{2}$

Hasil wawancara dengan kepala sekolah Ibu Herti, S. Pd terkait pendidikan karakter berbasis fitrah ini merupakan kurikulum yang masih langka digunakan, untuk sekolah di kota Padangsidimpuan baru Yayasan Insan Kamil Mutiara Kids ini yang menerapkannya. ${ }^{3}$ Dari hasil observasi peneliti melihat siswa MI Terpadu sudah mandiri dan kreatif, kemudian kesadaran beribadah mereka juga sudah baik dan tertib. Memang diakui bahwa dari pengamatan peneliti di lapangan menunjukkan, guru dalam membentuk karakter Siswa MI Terpadu Mutiara Kota Padangsidimpuan sudah baik. Hal ini bisa terwujud karena tanggung jawab bersama dari para pendidik atau penyelenggara pendidikan di sekolah maupun para orang tua.

Adapun tujuan yang ingin dicapai dalam penelitian ini adalah :

1. Untuk mengetahui strategi guru dalam membentuk karakter Siswa MI Terpadu Mutiara Kota Padangsidimpuan.

2. Untuk mengetahui cara guru menerapkan karakter Siswa MI Terpadu Mutiara Kota Padangsidimpuan

\section{KAJIAN TEORI}

\section{Pengertian Strategi Pembelajaran}

Strategi adalah siasat atau taktik yang dilakukan guru kepada peserta didik dalam setiap aktivitas pengajaran. ${ }^{4}$ Strategi dalam pelaksanaan, yaitu upaya bagaimana mencapai tujuan atau sasaran yang ditetapkan sesuai dengan keinginan. Karena strategi merupakan upaya pelaksanaan, maka strategi pada hakikatnya merupakan suatu seni yang implementasinya didasari oleh intuisi, perasaan dan hasil pengalaman.

Tujuan dari penggunaan strategi adalah sebagai berikut :

${ }^{2}$ Masitoh, Strategi Pembelajaran....., hlm. 233

${ }^{3}$ Herti, S.Pd, Wawancara bersama Ibu Kepala Sekolah, Senin, tanggal 10 September 2018, Jam. 10:00 Wib

"Sudrajat, "Strategi Pembelajaran," Statewide Agricultural Land Use Baseline 2015 1, no. 2008 (2015): 17623470, https://doi.org/DOI: 10.1016/j.epsl.2010.11.015. 
a. Membantu guru memberikan informasi sebanyak-banyaknya kepada peserta didik.

b. Membantu peserta didik mengembangkan kemampuan berpikir, pemecahan masalah, dan keterampilan intelektual.

c. Belajar tentang berbagai peran orang dewasa melalui pelibatan mereka dalam pemgalaman nyata atau simulasi.

d. Menjadi pembelajar yang otonom dan mandiri.

Strategi pembelajaran adalah suatu kegiatan pembelajaran yang harus dikerjakan guru dan siswa agar tujuan pembelajaran dapat dicapai secara efektif dan efisien. ${ }^{5}$ Strategi pembelajaran merupakan suatu serangkaian rencana kegiatan yang termasuk didalamnya penggunaan metode dan pemanfaatan berbagai sumber daya atau kekuatan dalam suatu pembelajaran. ${ }^{6}$

Menurut Saiful Bahri Djamarah "Strategi pembelajaran adalah komponen-komponen dari suatu set materi termasuk aktivitas sebelum pembelajaran, dan partisipasi peserta didik yang merupakan prosedur pembelajaran yang digunakan kegiatan selanjutnya. ${ }^{7}$ Sebagaimana Trianto, mendefenisikan bahwa: Strategi pembelajaran merupakan cara-cara yang dipilih untuk menyampaikan metode pembelajaran dalam lingkungan pembelajaran tertentu. ${ }^{8}$

\section{Komponen Strategi Pembelajaran}

Pembelajaran merupakan suatu sistem instruksional yang mengacu pada seperangkat komponen yang saling bergantungan satu sama lain untuk mencapai tujuan. Sebagai sebuah sistem, pembelajaran meliputi suatu komponen, antara lain: tujuan, bahan, murid, guru, metode, dan evaluasi. Komponen dalam strategi pembelajaran akan dijabarkan dibawah ini: ${ }^{9}$

1. Guru. Guru adalah pelaku pembelajaran, sehingga dalam hal ini guru merupakan faktor yang terpenting.

${ }^{5}$ Wina Sanjaya, Pembelajaran dalam Implementasi Kurikulum Berbasis Kompetensi, (Jakarta: Kencana, 2006), hlm. 7

${ }^{6}$ Suryosubroto , Strategi Pembelajaran (Jakarta, Kencana Prenada Media Group, 2006), hlm 40

7Syaiful Bahri Djamarah and Aswan Zain, "Guru Dan Anak Didik Dalam Interaksi Edukatif Suatu Pendekatan Teoritis Psikologis," Jakarta:Rineka Cipta, 2010, hlm.239, https://doi.org/http://dx.doi.org/10.1016/S0278-6125(98)80001-0.

${ }^{8}$ Trianto, Mendesain Model Pembelajaran Inovatif-Progresif (Jakarta: Kencana Presada Media Group, 2009),hlm 39

${ }^{9}$ Hamruni, Strategi Pembelajaran (Yogjakarta:Insan, 2011), hlm. 11-13 
2. Murid. Murid merupakan komponen yang melakukan kegiatan belajar untuk mengembangkan potensi kemampuan menjadi nyata guna mencapai tujuan belajar.

3. Tujuan. Tujuan merupakan dasar yang dijadikan landasan untuk menentukan strategi, materi, media dan evaluasi pembelajaran

4. Bahan pelajaran. Bahan pelajaran merupakan medium untuk mencapai tujuan pembelajaran yang berupa materi yang tersusun secara sistematis dan dinamis sesuai dengan arah tujuan dan perkembangan kemajuan ilmu pengetahuan dan tuntutan masyarakat.

5. Kegiatan pembelajaran. Agar tujuan pembelajaran dapat dicapai secara optimal, maka dalam menentukan strategi pembelajaran perlu dirumuskan komponen kegiatan pembelajaran yang sesuai dengan standar proses pembelajaran.

6. Metode. Metode adalah cara yang dipergunakan untuk mencapai tujuan pembelajaran yang telah ditetapkan

7. Alat. Alat yang dipergunakan dalam pembelajaran merupakan segala sesuatu yang dapat digunakan untuk mencapai tujuan pembelajaran.

8. Sumber belajar. Sumber belajar adalah segala sesuatu yang dapat dipergunakan sebagai tempat atau rujukan di mana bahan pembelajaran bisa diperoleh.

9. Evaluasi. Evaluasi merupakan komponen yang berfungsi untuk mengetahui apakah tujuan yang telah ditetapkan telah tercapai atau belum.

10. Situasi lingkungan. Lingkungan sangat mempengaruhi guru dalam menentukan strategi pembelajaran.

Komponen-komponen strategi pembelajaran tersebut akan mempengaruhi jalannya pembelajaran, karena semuanya merupakan faktor yang berpengaruh terhadap strategi pembelajaran.

\section{Membentuk Karakter}

\section{Pengertian Karakter}

Karakter secara harafiah berarti "kualitas mental atau moral, kekuatan moral, nama atau reputasi. karakter adalah kualitas atau kekuatan mental atau moral, akhlak atau budi pekerti individu yang merupakan kepribadian khusus yang menjadi pendorong atau penggerak, serta yang membedakan dengan 
individu lain. Seseorang dapat dikatakan berkarakter ketika orang tersebut telah berhasil menyerap nilai dan keyakinan yang dikehendaki masyarakat serta digunakan sebagai kekuatan moral dalam hidupnya.

Karakter diartikan sebuah tabiat, watak, sifat-sifat kejiwaan, akhlak atau budi pekerti yang membedakan seseorang dari orang lain. Karakter merupakan nilai-nilai perilaku manusia yang berhubungan dengan Tuhan Yang Maha Esa, diri sendiri, sesame manusia, lingkungan dan kebangsaan yang terwujud dalam pikiran, sikap, perasaan, perkataan, dan perbuatan berdasarkan norma-norma agama, hukum, tata krama, budaya dan adat istiadat. Karakter merupakan sifat kejiwaan, akhlak atau budi pekerti yang menjadi ciri khas seseorang atau sekelompok orang. ${ }^{10}$

\section{Pendidikan Karakter}

Pendidikan karakter yang utuh dan menyeluruh tidak hanya membentuk murid menjadi pribadi yang cerdas dan baik, melainkan juga membentuk mereka menjadi pelaku bagi perubahan dalam hidupnya sendiri, yang akhirnya akan menyumbangkan perubahan dalam tatanan sosial kemasyarakatan menjadi lebih, adil, baik dan manusiawi.

Pendidikan karakter adalah suatu sistem penanaman nilai-nilai karakter kepada warga sekolah yang meliputi komponen pengetahuan, kesadaran atau kemauan, dan tindakan untuk melaksanakan nilai-nilai tersebut, baik terhadap Tuhan Yang Maha Esa (YME), diri sendiri, sesama, lingkungan, maupun kebangsaan sehingga menjadi manusia insan kamil. Dalam pendidikan karakter di sekolah, semua komponen (stakeholders) harus dilibatkan, termasuk komponen-komponen pendidikan itu sendiri, yaitu isi kurikulum, proses pembelajaran dan penilaian, kualitas hubungan, penanganan atau pengelolaan mata pelajaran, pengelolaan sekolah, pelaksanaan aktivitas, pemberdayaan sarana prasarana, pembiayaan, dan etos kerja seluruh warga dan lingkungan sekolah. ${ }^{11}$

Oleh karena itu, pendidikan karakter dapat diintegrasikan dalam pembelajaran pada setiap mata pelajaran. Materi pembelajaran yang berkaitan dengan norma atau nilai-nilai pada setiap mata pelajaran perlu dikembangkan, dieksplisitkan, dikaitkan dengan konteks kehidupan sehari-hari. Dengan

${ }^{10}$ Dimiyati dan Mujiono, Belajar Dan Pembelajaran, (Jakarta: Rineka Cipta,2006), hlm 80

${ }^{11}$ Khairiyah Husain Thaha, Konsep Ibu Teladan ( Surabaya: Risalah Gusti, 1992), hlm. 71-72 
demikian pembelajaran nilai-nilai karakter tidak hanya pada tataran kognitif, tetapi menyentuh pada internalisasi dan pengamalan nyata dalam kehidupan peserta didik sehari-hari di masyarakat.

Pendidikan karakter di sekolah sangat terkait dengan manajemen atau pengelolaan sekolah. Pengelolaan yang dimaksud adalah bagaimana pendidikan karakter direncanakan, dilaksanakan, dan dikendalikan dalam kegiatan-kegiatan pendidikan di sekolah secara memadai. Pengelolaan tersebut antara lain meliputi, nilai-nilai yang perlu ditanamkan, muatan kurikulum, pembelajaran, penilaian, pendidik dan tenaga kependidikan, dan komponen terkait lainnya. Dengan demikian, manajemen sekolah merupakan salah satu media yang efektif dalam pendidikan karakter di sekolah.

Pendidikan karakter bertujuan untuk meningkatkan mutu penyelenggaraan dan hasil pendidikan di sekolah yang mengarah pada pencapaian pembentukan karakter dan akhlak mulia peserta didik secara $u t u h$, terpadu, dan seimbang, sesuai standar kompetensi lulusan. Melalui pendidikan karakter diharapkan siswa didik mampu secara mandiri meningkatkan dan menggunakan pengetahuannya, mengkaji dan menginternalisasi serta mempersonalisasi nilai-nilai karakter dan akhlak mulia sehingga terwujud dalam perilaku sehari-hari. Pendidikan karakter nantinya diharapkan menjadi budaya sekolah. ${ }^{12}$

\section{Pembentukan Karakter}

Membentuk karakter tidak bisa dilakukan dalam sekejap dengan memberikan nasihat, perintah, atau instruksi, namun lebih dari hal tersebut. Pembentukan karakter memerlukan teladan/role model, kesabaran, pembiasaan, dan pengulangan. Dengan demikian, proses pendidikan karakter merupakan proses pendidikan yang dialami oleh murid sebagai bentuk pengalaman pembentukan kepribadian melalui mengalami sendiri nilai-nilai kehidupan, agama, dan moral. ${ }^{13}$

Ada tiga tahap pembentukan karakter, yakni:

1. MORAL KNOWING: Memahamkan dengan baik pada anak tentang arti kebaikan. Mengapa harus berperilaku baik. Untuk apa berperilaku baik. Dan apa manfaat berperilaku baik.

${ }^{12}$ Khairiyah Husain Thaha, Konsep Ibu Teladan.... hlm. 149.

${ }^{13}$ Dedi Supriadi, Mengangkat Citra dan Martabat Guru (Yogyakarta: Adicita Karya Nusa, 2000), hlm.95 
226 | TAZKIR: Jurnal Penelitian Ilmu-ilmu Sosial dan Keislaman

Vol. 04 No. 2 Desember 2018

2. MORAL FEELING: Membangun kecintaan berperilaku baik pada anak yang akan menjadi sumber energi anak untuk berperilaku baik. Membentuk karakter adalah dengan cara menumbuhkannya.

3. MORAL ACTION: Bagaimana membuat pengetahuan moral menjadi tindakan nyata. Moral action ini merupakan outcome dari dua tahap sebelumnya dan harus dilakukan berulang-ulang agar menjadi moral behavior $^{14}$

Dengan melalui tiga tahap tersebut, proses pembentukan karakter akan menjadi lebih mengena dan murid akan berbuat baik karena dorongan internal dari dalam dirinya sendiri. Ada 9 pilar karakter yang harus ditumbuhkan dalam diri murid:

1. Cinta pada Allah SWT, dengan segenap ciptaanNya

2. Kemandirian dan tanggung jawab

3. Kejujuran, bijaksana

4. Hormat, santun

5. Dermawan, suka menolong, gotong royong

6. Percaya diri, kreatif, bekerja keras

7. Kepemimpinan, keadilan

8. Baik hati, rendah hati

9. Toleransi, Kedamaian, kesatuan ${ }^{15}$

Ketika guru ingin menguatkan karakter kerjasama, disiplin waktu, keberanian, dan percaya diri, maka guru perlu memberikan kegiatan-kegiatan dalam proses pembelajaran sehari-hari. Guru perlu menyadari bahwa guru harus memberikan banyak perhatian pada karakter yang ingin dikembangkan ketika proses pembelajaran sedang berlangsung. Seperti kita ketahui bahwa belajar tidak hanya untuk mendapatkan ilmu pengetahuan saja, namun juga dapat menerapkan ilmu pengetahuan dalam bentuk karya yang mencerminkan keterampilan dan meningkatkan sikap positif.

\section{METODE PENELITIAN}

Penelitian ini dilakukan dengan metode kualitatif dengan mendeskripsikan penomena yang ada di lapangan. Penelitian ini dilakukan pada siswa MI

${ }^{14}$ Dedi Supriadi, Mengangkat Citra... hlm. 96

${ }^{15}$ A. Samana, Profesionalisme Keguruan (Yogyakarta: Kanisius,1994), hlm. 27 
Terpadu Mutiara Kota Padangsidimpuan, dengan mengambil informan guruguru untuk mengetahui strategi guru dalam membentuk karakter siswa. Data dikumpulkan melalui observasi dan wawancara, lalu dilakukan analisis dengan menyajikan data, mengelompokkan, dan melakukan interpretasi terhadap data yang dipeorleh.

\section{HASIL PENELITIAN DAN PEMBAHASAN}

\section{Strategi Guru dalam Membentuk Karakter Siswa MI Terpadu Mutiara Kota Padangsidimpuan}

Strategi adalah prosedur yang diterima dan dipakai dalam suatu upaya untuk mencapai tujuan-tujuan tertentu, seperti pemecahan suatu masalah. Dalam melaksanakan strategi, metode sebagai acuan konseptual dan teknik sebagai pelaksanaan sangat diperlukan. MI Terpadu Mutiara menerapkan strategi dalam usaha membentuk karakter murid dengan tetap menaati aturan dan memanfaatkan sarana dan parasarana sekolah, tenaga kependidikan dan guru yang profesional dan lingkungan sekolah sebagai media belajar. ${ }^{16}$ Untuk menciptakan siswa yang karakter salah satunya cara dengan memadukan semua mata pelajaran dengan ayat Alquran dan karakter qurani ini harus terus ditanamkan pada diri siswa.

Penerapan strategi ini meliputi seluruh proses pembelajaran baik sebelum, selama dan setelah proses pembelajaran. Strategi yang diterapkan juga disesuaikan dengan aturan yaitu Peraturan Menteri Pendidikan, serta mengacu kepada Kurikulum K13. Strategi yang diterapkan oleh guru meliputi seluruh aspek pendidikan yaitu murid, guru, sarana dan prasarana, kelas dan strategi pembelajaran yang dilakukan.

Guru dapat membantu murid yang mengalami kesulitan belajar dengan menggunakan strategi mengajar. Dengan strategi mengajar yang lebih efektif, yang artinya proses pembentukan karakter bagi murid juga lebih mudah. ${ }^{17}$ Tugas guru mencakup kegiatan pokok yaitu merencanakan pembelajaran, melaksanakan pembelajaran, menilai hasil pembelajaran, membimbing dan melatih siswa, serta melaksanakan tugas tambahan. Latar belakang guru yang

${ }^{16}$ Rahma, S.Pd, Guru Kelas, Wawancara di ruang guru, Senin, tanggal 17 Oktober 2018, Jam 10.00 Wib.

${ }^{17}$ Nirwana, S.Pd, Wawancara di ruang guru, Selasa, tanggal 18 September 2018, Jam 10.00 Wib 
berkependidikan S1 dan telah ikut dalam penataran, pelatihan dan pendidikan bagi. Dengan demikian guru mempunyai kompetensi mengajar yang sesuai, yang relevan dalam membentuk karakter murid.

Strategi yang diterapkan untuk membentuk karakter murid juga menyangkut dalam penggunaan instrumen-instrumen pendidikan, kapan digunakan, bagaimana menggunakan dan kepada siapa-siapa instrumen dipakai. Bentuk instrumen-instrumen tersebut adalah test tertulis dengan essay, test tertulis dengan pilihan ganda, pekerjaan rumah (PR), penugasan.

Wawancara peneliti tentang gambaran strategi guru kelas adalah bahwa beliau menerapkan beberapa strategi untuk pembelajaran ketika proses belajar mengajar berlangsung. ${ }^{18}$ Berdasarkan hasil wawancara penulis dengan guru kelas yang mengatakan bahwa untuk menerapkan strategi pembelajaran terkadang berperan sebagai pembimbing, dan terkadang juga sebagai supervisor, fasilisator, mediator, dan komentator. ${ }^{19}$

Dalam menerapkan strategi pembelajaran terdapat empat tahap yang digunakan yaitu :

1. Guru merangsang siswa dengan pertanyaan, masalah, permainan, tekateki, dan lain-lain.

2. Sebagai jawaban atas rangsangan yang diterimanya, siswa menentukan prosedur mencari dan mengumpulkan informasi atau data yang diperlukannya untuk memecahkan pertanyaan atau masalah. Siswa bekerja sendiri-sendiri atau berkelompok.

3. Siswa menghayati tentang pengetahuan yang diperolehnya dengan inquiri (menemukan) yang baru dilaksanakan.

4. Siswa menganalisis inquiri (menemukan) dan prosedur yang ditemukan untuk dijadikan metode umum yang dapat diterapkannya ke situasi lain.

\section{Strategi Dalam Menerapkan Karakter Siswa MI Terpadu Mutiara Kota Padangsidimpuan}

Strategi dalam menerapkan karakter di MI Terpadu Padangsidimpuan yang dapat berperan dalam pembentukan karakter siswa adalah dengan menggunakan pendekatan dan metode yang tepat antara lain pendekatan saling

${ }^{18}$ Nirwana, S.Pd, Wawancara di ruang guru, Selasa, tanggal 18 September 2018, Jam 10.30 Wib.

${ }^{19}$ Nirwana, S. Pd, Wawancara di ruang guru, selasa tanggal 18 September 2018, Jam 11:00 Wib. 
kenal, pendekatan discovery inkuiri, pendekatan CTL, pendekatan kooperatif, pendekatan kuantum dengan metode ekspresimen atau demonstrasi, diskusi presentasi, karya wisata, simulasi, latihan dan penugasan. ${ }^{20}$

Siswa yang menjadi objek dan subjek pendidikan di MI Terpadu merupakan individu-individu yang karakternya dapat dibentuk seperti siswa normal pada umumnya. Sebagaimana yang disampaikan oleh guru kelas, murid merupakan individu yang masih mungkin dibentuk karakternya meskipun dengan strategi yang khusus. ${ }^{21}$ MI Terpadu ingin menghasilkan kompetensi karakter siswa sebagai berikut:22

1. Siswa Mandiri

Siswa MI Terpadu diharapkan mampu membangun kemandirian pribadinya. Program pendidikan dengan strategi pembelajarannya difokuskan untuk memberi bekal mental dan keterampilan murid untuk dapat mengurus diri sendiri meskipun dengan keterbelakangan dan kekurangan berbeda yang dimiliki setiap murid sebelum menempuh pendidikan. Murid diajarkan untuk bisa melayani diri sendiri, melaksanakan perintah-perintah sederhana dan pekerjaan sehari-hari setelah menempuh pendidikan di MI Terpadu tanpa degan supervisi/pengawasan dari orang lain.

2. Murid Berkemampuan Optimal (Moral Feeling)

Strategi pembelajaran yang diterapkan oleh guru MI Terpadu dimaksudkan untuk mengoptimalkan kecerdasan murid. Mengisi dan mengasah kemampuan murid dengan ilmu agama Islam, membekali murid dengan ketaqwaan kepada Allah SWT dan menghadirkan murid dengan karakter yang berakhlak mulia. Strategi pembelajaran juga diharapkan mampu membekali murid dengan kompetensi pribadi yang optimal.

3. Murid Berakhlak Muliam (Moral Action)

Siswa MI Terpadu diharapkan memiliki kepribadian yang unggul, kepribadian yang sesuai dengan ajaran agama Islam, kepribadian yang sesuai dengan yang diajarkan oleh Nabi Muhammad SAW. Dengan kemandirian dan kemampuan yang optimal, diharapkan siswa MI Terpadu mampu membiasakan

${ }^{20}$ Nirwana, S.Pd.I, Wawancara di ruang guru, Selasa, tanggal 18 September 2018, Jam 11.30 Wib.

${ }^{21}$ Rahma, S. Pd, Wawancara di ruang guru, Rabu tanggal 19 September 2018, Jam 10:00 Wib.

${ }^{22}$ Rahma, S. Pd, Wawancara di ruang guru, Rabu tanggal 19 September 2018, Jam 10:30 Wib 
diri untuk melaksanakan amal yang baik, menghindari amal yang tidak baik dan mampu menjadi insan yang berkepribadian mulia baik dalam pandangan keluarga, lingkungan, masyarakat dan lebih lagi dalam pandangan Allah SWT.

Dengan melalui tiga tahap tersebut, proses pembentukan karakter akan menjadi lebih mengena dan murid akan berbuat baik karena dorongan internal dari dalam dirinya sendiri. Ada 9 pilar karakter yang harus ditumbuhkan dalam diri murid:

1) Cinta pada Allah SWT, dengan segenap ciptaanNya. Siswa diharapkan cinta kepada Allah SWT, Sikap ini selalu ditanamkan kepada mereka

2) Kemandirian adalah sikap ini ditanamkan pada saat menyelesaikan tugas dengan mandiri

3) Kejujuran adalah perilaku yang sangat mulia dan menjadi tombak keberhasilan dalam menerapkan karakter kepada siswa.

4) Hormat, santun adalah sikap, perkataan, dan tindakan yang menyebabkan orang lain merasa senang dan aman atas kehadiran dirinya.

5) Dermawan, suka menolong, gotong royong adalah perilaku yang menunjukkan upaya sungguh-sungguh dalam mengerjakan tugas kelompok dengan saling menbantu baik tugas di dalam kelas maupun di luar kelas

6) Percaya diri, kreatif, bekerja keras adalah melakukan sesuatu untuk menghasilkan karya yang baik dan kreatif.

7) Kepemimpinan, keadilan adalah sikap dan tindakan yang selalu ingin memberi bantuan pada orang lain dan masyarakat yang membutuhkan.

8) Baik hati, rendah hati adalah sikap, perkataan yang ditanamkan kepada siswa dengan berempati atas masalah yang dihadapi kawannya.

9) Toleransi, Kedamaian, kesatuan adalah sikap dan tindakan yang menghargai antar sesama siswa dan.

Menurut guru kelas, Ibu Nirwana, S.Pd. ${ }^{23}$. Metode penanaman 9 pilar karakter tersebut dilakukan secara eksplisit dan sistematis, yaitu dengan moral knowing, moral feeling, moral action ternyata telah berhasil membangun karakter murid. Dengan moral knowing murid terbiasa berpikir hanya yang baik-baik saja.

${ }^{23}$ Nirwana, S.Pd, Guru PAI, Wawancara di ruang guru, Senin, tanggal 24 September 2018, Jam 10.00 Wib. 
Moral knowing juga perlu dilakukan supaya murid tahu mengapa dia harus berbuat baik. Misalnya kenapa murid harus jujur, apa akibatnya kalau murid jujur, dan sebagainya. Jadi murid tidak hanya menghafal kebaikan tetapi juga tahu alasannya. Dan juga dengan moral feeling, kita membangun perasaan murid akan kebaikan. Murid diharapkan mencintai kebaikan. Lalu, dalam moral action, murid mempraktekkan kebaikan. Jika murid terbiasa melakukan moral knowing, moral feeling, moral action lama kelamaan murid akan terbentuk karakternya.

Dalam kegiatan proses pembelajaran, membentuk murid berkarakter dapat dimulai dari pembuatan perencanaan pelaksanaan pembelajaran (RPP). Karakter yang akan dikembangkan dapat ditulis secara eksplisit pada RPP. Dengan demikian, dalam setiap kegiatan pembelajaran guru perlu menetapkan karakter yang akan dikembangkan sesuai dengan materi, metode, dan strategi pembelajaran. Ketika guru ingin menguatkan karakter kerjasama, disiplin waktu, keberanian, dan percaya diri, maka guru perlu memberikan kegiatan-kegiatan dalam proses pembelajaran sehari-hari. Guru perlu menyadari bahwa guru harus memberikan banyak perhatian pada karakter yang ingin dikembangkan ketika proses pembelajaran sedang berlangsung. Seperti kita ketahui bahwa belajar tidak hanya untuk mendapatkan ilmu pengetahuan saja, namun juga dapat menerapkan ilmu pengetahuan dalam bentuk karya yang mencerminkan keterampilan dan meningkatkan sikap positif.

\section{PENUTUP}

Strategi Guru Dalam Membentuk Karakter siswa MI Terpadu Padangsidimpuan baik dan bagus sehingga siswa dapat melaksanakan pembiasaan yang baik dalam kehidupan sehari - hari ketika di sekolah maupun di rumah.

Adapun Strategi Guru Dalam Membentuk Karakter siswa MI Terpadu Padangsidimpuan yaitu: Guru menerapkan metode pembelajaran yang melibatkan partisipatif aktif murid, Guru perlu menciptakan lingkungan belajar yang kondusif., Guru merangsang murid dengan pertanyaan, masalah, permainan, teka-teki, dan lain-lain, Guru mengaitkan materi yang akan dipelajari dengan Alquran., Guru memberikan pendidikan karakter secara eksplisit, sistematis, dan berkesinambungan dengan melibatkan aspek moral knowing, moral feeling, moral action. 
232 | TAZKIR: Jurnal Penelitian Ilmu-ilmu Sosial dan Keislaman

Vol. 04 No. 2 Desember 2018

\section{DAFTAR PUSTAKA}

Djamarah, Syaiful Bahri, and Aswan Zain. "Guru Dan Anak Didik Dalam Interaksi Edukatif Suatu Pendekatan Teoritis Psikologis." Jakarta:Rineka Cipta, 2010, 2010. $\quad$ https://doi.org/http://dx.doi.org/10.1016/S02786125(98)80001-0.

Husain Thaha, Khairiyah. 1992. Konsep Ibu Teladan. Surabaya: Risalah Gusti.

Masitoh. 2009. Strategi Pembelajaran. Jakarta: Depaq RI.

Mujiono, Dimiyati. 2006. Belajar Dan Pembelajaran. Jakarta: Rineka Cipta.

Rohani, Ahmad. 1991. Pengelolaan Pengajaran. Jakarta: Rineka Cipta.

Samana, A. 1994. Profesionalisme Keguruan. Yogyakarta: Kanisius.

Sanjaya, Wina. 2006. Pembelajaran dalam Implementasi Kurikulum Berbasis Kompetensi. Jakarta: Kencana.

Sudrajat. "Strategi Pembelajaran." Statewide Agricultural Land Use Baseline 2015 1, no. 2008 (2015): 17623470. https://doi.org/DOI: 10.1016/j.epsl.2010.11.015.

Supriadi, Dedi. 2000. Mengangkat Citra dan Martabat Guru. Yogyakarta: Adicita Karya Nusa.

Suryosubroto. 2006. Strategi Pembelajaran. Jakarta: Kencana Prenada Media Group.

Trianto. 2009. Mendesain Model Pembelajaran Inovatif-Progresif. Jakarta: Kencana Presada Media Group. 